\title{
EVALUASI IMPLEMENTASI STANDAR PENILAIAN OLEH GURU MATEMATIKA DI SMA NEGERI 3 WATAMPONE KABUPATEN BONE
}

\author{
Muh Bachtiar Aziz ${ }^{1}$ \\ tiarejie@gmail.com \\ Prodi Manajemen Pendidikan Islam IAIN Bone ${ }^{1}$
}

\begin{abstract}
This study aims to describe the assesment planning, overview of assesment implementation, and reporting result/impact of the assesment at SMA 3 Watampone, based on the aspects of antecedents, transactions, and outcomes. This research is an evaluation study which is used by mathematical teachers at SMAN 3 Watampone. Data were analyzed using descriptive data analysis in the form of frequency distribution and percentages. Subjects in this study were the principal, vice principal, math teachers, and students. Data were collected by employing questionnare, interview, and documentation. The result shows that evaluation results of the implementation of assesment standard by mathmatics teacher at SMAN 3 Watampone based on recapitulation aspects of planning (antecedents), implementation (transactions), and result/impacts (outcomes) are in the good category. It is harmonized by (1) Planning Assesment, the school provide a syllabus and assesment guidelines that serve as a giude for teachers. (2) The implementation of assesment, assesment activities such as the provision of assignments and quizzes are in conformity with the plan thats is prepared at the beginning of learning activities. (3) Results/impact, teacher processing, scoring, input the score in the valuation list, then report the result to the class teacher, school principal, and invite the parents/guardians of the students.
\end{abstract}

Keywords: evaluation program, assessment standard, mathematics

\section{PENDAHULUAN}

Dalam mendefinisikan evaluasi, para ahli memiliki sudut pandang yang berbeda, sesuai dengan bidang keahlian masing-masing. Namun muara pada semua definisi mereka menuju ke suatu titik, yaitu proses penetapan keputusan tentang objek yang dievaluasi. Para ahli yang menekuni bidang industry tentunya objek yang dievaluasi berkaitan dengan masalah industri. Ahli yang menekuni bidang pendidikan juga akan banyak bercerita yang berkaitan 
dengan masalah pendidikan seperti kinerja, prestasi belajar, manajemen kelas, kompetensi guru, iklim akademis, dan seterusnya (Mansyur dkk ; 2009).

Ada tiga istilah yang sering digunakan dalam evaluasi, yaitu tes, pengukuran dan penilaian. Tes merupakan salah satu cara untuk menaksir besarnya kemampuan seseorang secara tidak langsung, yaitu melalui respons seseorang terhadap stimulus atau pernyataan (Mardapi, 2012:108).

Hasil evaluasi pendidikan merupakan informasi yang sangat berguna bagi pengelola pendidiakn baik yang berada pada tingkat pusat, provinsi, kabupaten/kota, maupun secular. Salah satu tujuan evaluasi pendidikan untuk meningkatkan kualitas pendidkan tampak belum berhasil. Hal ini dapat dilihat dari perkembangan kualitas pendidikan dari tahun ketahun yang tidak berubah, walau berfluktuasi namun masih dalam kategori rendah. Keadaan ini mennjkkan bahwa hasil evaluasi kemungkinan belum memberikan informasi yang akurat dan rinci untuk perbaikan kualitas pendidikan (Mansyur dkk 2009).

Pendidikan merupakan hal yang sangat penting untuk menjamin perkembangan serta kelangsungan kehidupan berbangsa dan bernegara. Pendidikan adalah usaha sadar dan terencana untuk mewujudkan suasana belajar dan proses pembelajaran agar peserta didik secara aktif mengembangkan potensi dirinya untuk memiliki kekuatan spiritual keagamaan, pengendalian diri, kepribadian, kecerdasan, akhlak mulia, serta keterampilan yang diperlukan dirinya, masyarakat, bangsa dan negara (UU No. 20 Tahun 2003).

Menurut Yasin (2010), Aspek penting lain dalam pengelolaan pembelajaran adalah evaluasi atau penilaian. Evaluasi atau penilaian dalam pembelajaran tidak semata-mata dilakukan terhadap hasil belajar, tetapi juga harus dilakukan terhadap proses pembelajaran itu sendiri. Dengan kata lain, ia dapat berfungsi sebagai umpan balik dan remedial pembelajaran.

Selain itu, kegiatan penilaian haruslah dilakukan secara terencana dengan baik. Kegiatan penilaian yang dilakukan hanya dengan mengandalkan tekhnik pengamatan saja tampaknya kurang dapat dipertanggungjawabkan karena unsur subjektifitas penilai sangat berperan. Tidak jarang terjadi bahwa apa yang dilihat mata dan diamati, misalnya tingkah laku hasil belajar peserta didik, tidak mencerminkan keadaan atau kemampuan yang mendekati sebenarnya. Mimin Haryati (2006: 15) mengemukakan ada empat macam istilah yang berkaitan dengan konsep penilaian dan digunakan untuk mengetahui keberhasilan penilaian dari pada peserta didik yaitu pengukuran, pengujian, penilaian dan evaluasi.

Menurut Silvina (2005: 17) menyatakan bahwa sebenarnya proses pengukuran, penilaian, evaluasi dan pengujian merupakan suatu kegiatan atau proses yang bersifat hirarkis. 
Artinya kegiatan dilakukan secara berurutan dan berjenjang yaitu dimulai dari proses pengukuran kemudian penilaian dan terakhir evaluasi.

Sedangkan menurut Sutomo (1985:16) penilaian adalah suatu tindakan atau langkah untuk menentukan mutu atau kualitas dari sesuatu. Pendapat yang sama dikemukakan pula oleh Mimin Haryati (2006:16) bahwa penilaian adalah suatu pernyataan berdasarkan sejumlah fakta untuk menjelaskan karateristik seseorang atau sesuatu.

Berdasarkan pendapat para ahli diatas dapat disimpulkan bahwa proses penilaian mencakup pengumpulan bukti untuk menunjukan pencapaian belajar dari pada peserta didik. Definisi penilaian berhubungan erat dengan setiap bagian kegiatan belajar mengajar. Ini menunjukan bahwa proses penilaian tidak hanya menyangkut hasil belajar saja tetapi juga mengangkut semua proses belajar mengajar.

Mutu pendidikan secara umum tidak terlepas dari kualitas penggunaan instrumen evaluasi yang relevan. Keduanya terkait erat dengan kemampuan guru dalam mengajar dan akhirnya berdampak pada prestasi belajar siswa. Guru sebagai tenaga akademik dituntut memiliki sifat profesional keguruan yang handal dan bertanggung jawab untuk melaksanakan tugas dan fungsinya sebagai pegajar dan pendidik disekolah. Guru harus mampu mengembangkan aspek kognitif, afektif dan psikomotor pada siswa (termasuk dalam mengembangkan penilaian), sehingga siswa tidak hanya menguasai pengetahuan tetapi juga memiliki sikap dan akhlak yang terpuji. Untuk itu, Guru harus menguasai kompetensi keguruan diantaranya yang berkaitan dengan pelaksanaan, pengelolahan dan tindak lanjut evaluasi.

Sistem pendidikan nasional tersebut harus mampu menjamin pemerataan kesempatan pendidikan, peningkatan mutu serta relevansi dan efisiensi manajemen pendidikan untuk menghadapi tantangan sesuai dengan tuntutan perubahan kehidupan lokal, nasional, dan global. Agar tercapainya tujuan pendidikan nasional, maka dibentuklah suatu sistem pendidikan nasional yang merupakan keseluruhan komponen pendidikan yang saling terkait secara terpadu untuk pencapaian tujuan tersebut. Oleh sebab itu, sistem pendidikan di seluruh wilayah hukum Negara Kesatuan Republik Indonesia memiliki standar yang sama.

Dalam Pasal 1 ayat (17) Undang-undang nomor 20 tahun 2003 tentang Sistem Pendidikan Nasional yang tertuang dalam Pasal 2 Ayat (1) PP No. 19 tahun 2005 dinyatakan bahwa lingkup dari Standar Nasional Pendidikan meliputi 8 standar yaitu: (1) standar isi, (2) standar proses, (3) standar kompetensi lulusan, (4) standar pendidik dan tenaga kependidikan, 
(5) standar sarana dan prasarana, (6) standar pengelolaan, (7) standar pembiayaan, dan (8) standar penilaian pendidikan.

Standar penilaian pendidikan merupakan salah satu bagian dari Standar Nasional Pendidikan tentang sistem pendidikan di seluruh wilayah hukum Negara Kesatuan Republik Indonesia. Oleh sebab itu, setiap pendidik harus memahami landasan yuridis maupun filosofis yang melatarbelakangi munculnya standar penilaian, mekanisme, dan prosedur evaluasi. Termasuk dalam hal tersebut, bagaimana pendidik menetapkan indikator keberhasilan pembelajaran dan merancang pengalaman belajar siswa.

Standar penilaian pendidikan adalah standar nasional pendidikan yang berkaitan dengan mekanisme, prosedur, dan instrumen penilaian hasil belajar peserta didik. Pada lampiran bagian mekanisme dan prosedur, dinyatakan bahwa penilaian pendidikan pada jenjang pendidikan dasar dan menengah dilakukan oleh pendidik, satuan pendidikan dan pemerintah. ( Permendiknas No.20 Tahun 2007)

Tujuan penilaian adalah untuk mengetahui tingkat pencapaian kompetensi yang diperoleh peserta didik, sebagai bahan penyusunan laporan kemajuan hasil belajar, dan memperbaiki proses pembelajaran berdasarkan Kurikulum yang berlaku. Penilaian diperoleh melalui teknik tes maupun non-tes dari berbagai perangkat ukur maupun bentuk lainya (tes tertulis, lisan, atau kinerja) dan dilakukan secara konsisten, sistematis dan terprogram. Penilaian hasil belajar semestinya menggunakan standar penilaian pendidikan dan panduan penilaian kelompok mata pelajaran yang telah disusun oleh Badan Standar Nasional Pendidikan (BSNP).

Dalam penilaian selalu mengandung proses. Proses prenilaian harus tepat terhadap tipe tujuan pembelajaran. Dikarenakan tidak semua tujuan pembelajaran dapat dinyatakan dengan alat penilaian yang sama, maka penilaian menjadi salah satu hal yang sulit dan menantang, yang harus disadari oleh para guru.

Definisi yang pertama dikembangkan oleh Raplh Tyler (1950), ahli ini mengatakan bahwa evaluasi merupakan sebuah proses pengumpulan data untuk menentukan sejauh mana, dalam hal apa, dan bagian mana tujuan pendidikan sudah tercapai. Jika belum, bagaimana yang belum dan apa sebabnya. Definisi yang lebih luas dikemukakan oleh dua orang ahli lain, yakni Cronbach dan Stufflebeam. Tambahan definisi tersebut adalah bahwa proses evaluasi bukan sekadar mengukur sejauh mana tujuan tercapai, tetapi digunakan untuk membuat keputusan. (Dr. Suharsimi Arikunto. 1995: 3) 
Berdasarkan hasil wawancara yang dilakukan dengan beberapa guru di Sekolah Menengah Atas (SMA) Negeri 3 Watampone bahwa guru hanya memahami penilaian secara konvensional, artinya penilaian dilakukan guru jika mendekati tengah semester dan akhir semester saja. Hasil dari 3 guru yang peneliti wawancarai diobservasi awal bahwa kegiatan guru dalam menilai hanya dilakukan untuk prestasi belajar siswa pada akhir semester tanpa melakukan koreksi perangkat pembelajaran sehingga guru tidak melakukan pembaharuan dan perbaikan terhadap program pembelajaran setiap tahunnya. Seharusnya ada mekanisme dan prosedur yang telah dikeluarkan oleh badan standar nasional pendidikan yang dapat dijadikan guru sebagai pedoman untuk diterapkan di sekolah. Hal ini sangat penting sekali bagi proses pendidikan baik untuk siswa, guru dan sekolah. Ini merupakan masalah yang telah terjadi lemahnya penerapan penilaian yang berstandar sehingga penilaian itu tidak sama, artinya sesuai guru masing-masing.

Berdasarkan uraian di atas dan pentingnya masalah ini untuk diteliti, agar di peroleh data yang valid seberapa besar guru yang menerapkan penilaian sesuai standar penilaian dari Badan Standar Nasional Pendidikan (BSNP).

\section{METODE}

\section{Setting Penelitian}

Jenis penelitian adalah penelitian evaluasi dengan menggunakan Model Countenance Stake, yang meliputi evaluasi antecedents, transactions, dan output. Berdasarkan model evaluasi Stake penelitian ini membandingkan kesesuaian antara pelaksanaan proses penilaian dengan standar penilaian pendidikan sebagai kriteria standar untuk menilai tingkat keberhasilan pelaksanaan penilaian oleh guru.

Berdasarkan model evaluasi Stake standar penilaian oleh guru, maka desain evaluasi dapat dijabarkan sebagai berikut:

1. Tahap perencanaan (antecedents). Pada tahapan ini dilakukan evaluasi terkait pemahaman guru tentang prinsip penilaian, kesesuaian antara perencanaan penilaian secara terpadu dengan silabus dan rencana pembelajarannya, mengembangkan kriteria pencapaian Kompetensi Dasar (KD) sebagai dasar untuk penilaian, teknik penilaian dan instrumen penilaiannya sesuai indikator pencapaian $\mathrm{KD}$, membuat instrumen berdasar kisi-kisi yang telah dibuat dan dilengkapi dengan pedoman penskoran sesuai dengan teknik penilaian yang digunakan, serta menggunakan acuan kriteria dalam menentukan nilai siswa dengan standar penilaian pendidikan. 
2. Tahap pelaksanaan (transactions). Pada tahapan ini dilakukan evaluasi terkait kesesuaian antara pelaksanaan proses meliputi melakukan kegiatan penilaian sesuai dengan rencana penilaian yang telah disusun diawal kegiatan pembelajaran, menganalisis kualitas instrumen dengan mengacu pada persyaratan instrumen serta menggunakan acuan kriteria, pelaksanaan ulangan dan ujian yang bebas dari kemungkinan terjadi tindak kecurangan, serta memeriksa pekerjaan peserta didik dan memberikan umpan balik dan komentar yang bersifat mendidik dengan standar proses pendidikan.

3. Tahap hasil (Outcomes). Pada tahapan ini dilakukan evaluasi yang berfokus pada aspek output terkait kesesuaian antara penilaian hasil belajar meliputi pemberian skor untuk setiap komponen yang dinilai, penggabungan skor yang diperoleh dari berbagai teknik dengan bobot tertentu sesuai dengan aturan yang telah ditetapkan, serta pelaporan hasil penilaian kepada orang tua/ wali murid.

Subjek dalam penelitian ini adalah Kepala Sekolah, Wakil Kepala Sekolah, Guru, dan Siswa di SMA Negeri 3 Watampone Kabupaten Bone yang berjumlah 97 orang.

\section{Teknik Pengumpulan Data}

Untuk memperoleh data evaluasi penilaian oleh pendidik dilakukan dengan beberapa cara, yaitu wawancara, kuesioner dan dokumentasi dengan instrumen sebagai berikut :

1. pedoman wawancara, untuk memperoleh data perencanaan, pelaksanaan dan pelaporan hasil penilaian oleh pendidik

2. kuesioner, untuk memperoleh data perencanaan, pelaksanaan dan pelaporan hasil penilaian oleh pendidik

3. dokumentasi, untuk memperoleh data perencanaan penilaian oleh pendidik.

Data yang diperoleh dari ketiga instrumen tersebut selanjutnya dianalisis dengan metode kualitatif dan kuantitatif.

\section{Teknik Analisis Data}

Penelitian ini mendeskripsikan implementasi standar penilaian di SMA Negeri 3 Watampone. Pengolahan data dalam penelitian ini menggunakan empat tahapan, yaitu :

1. Pengumpulan data

Pengumpulan data peneliti lakukan dengan mengumpulkan data yaitu mencatat semua informasi dari stakeholder (pengelola, pendidik, dan peserta didik) secara objektif dan apa adanya sesuai dengan hasil kuesioner, wawancara, serta dokumentasi. 
2. Reduksi data

Mereduksi data berarti membuat rangkuman, memilih hal-hal pokok, memfokuskan pada hal-hal penting, mencari tema dan pola, serta membuang yang dianggap tidak perlu (Munarfah dan Hasan, 2009 : 168). Selama melaksanakan penelitian, maka jumlah data akan semakin banyak, rumit dan kompleks, untuk itu perlu dilakukan analisis data melalui reduksi data. Pilihan data yang tidak perlu akan dibuang, dan pilihan data yang perlu akan dikumpulkan lalu diverifikasi hingga dinyatakan tidak ada lagi yang dibuang.

3. Penyajian data

Langkah selanjutnya setelah data direduksi adalah mendisplay data. Dalam penelitian kualitatif, penyajian data dapat dilakukan dalam bentuk uraian singkat, bagan dan sejenisnya. Dalam hal ini Milles dan Humberman menyatakan yang paling sering digunakan untuk menyajikan data dalam penelitian kualitatif adalah dengan teks yang bersifat naratif.

Data yang diperoleh berdasarkan kuesioner terhadap peserta didik mengenai implementasi standar penilaian di SMA Negeri 3 Watampone, dianalisis dengan menggunakan model skala likert, yaitu dengan menentukan skor maksimal ideal dan minimal ideal. Selanjutnya dari rentangan skor tersebut dibuat kategori sangat baik, baik, cukup, kurang, dan sangat kurang. Berdasarkan Wayan Nurkancana \& Sumartana $(1983 ; 79-80)$ Maka langkah-langkah pembuatan tabel evaluasi implementasi standar penilaian di SMA Negeri 3 Watampone maka diperoleh tabel sebagai berikut

Tabel 1.1 Tabel pedoman konversi penskalaan

\begin{tabular}{cc}
\hline Interval & Kriteria \\
\hline$S k o r \geq M i+1,5 S D i$ & Sangat Baik \\
$M+0,5 S D i \leq$ skor $<M+1,5 S D i$ & Baik \\
$M-0,5 S D i \leq S k o r<M+0,5 S D i$ & Cukup \\
$M-1,5 S D i \leq S k o r<M-0,5 S D i$ & Kurang \\
Skor $<M-1,5 S D i$ & Sangat Kurang \\
\hline
\end{tabular}

\section{Keterangan}

$\mathrm{M}=$ Rata-rata ideal

Sdi $=$ Standar Deviasi ideal

Kriteria evaluasi berhubungan dengan kriteria yang telah ditetapkan sebelumnya. Dasar pertimbangannya adalah untuk memudahkan evaluator dalam mempertimbangkan nilai 
terhadap komponen program yang dinilai. Kriteria yang digunakan dalam evaluasi penilaian oleh guru seperti tercantum dalam Tabel 1.2

Tabel 2 Kriteria Evaluasi Standar Penilaian oleh Guru

\begin{tabular}{|c|c|}
\hline Komponen & Kriteria \\
\hline $\begin{array}{l}\text { 1. Perencanaan } \\
\text { (antecedents) }\end{array}$ & $\begin{array}{l}\text { 1. Kesesuaian antara perencanaan penilaian secara terpadu } \\
\text { dengan silabus dan rencana pembelajarannya, } \\
\text { 2. Mengembangkan kriteria pencapaian kompetensi dasar } \\
\text { (KD) sebagai dasar untuk penilaian, } \\
\text { 3. Teknik penilaian dan instrumen penilaiannya sesuai } \\
\text { indikator pencapaian KD, } \\
\text { 4. Membuat instrumen berdasarkan kisi-kisi yang telah } \\
\text { dibuat dan dilengkapi dengan pedoman penskoran sesuai } \\
\text { dengan teknik penilaian yang digunakan, } \\
\text { 5. Menggunakan acuan kriteria dalam menentukan nilai } \\
\text { peserta didik. }\end{array}$ \\
\hline $\begin{array}{ll}\text { 2. } & \text { Proses } \\
& (\text { transaction })\end{array}$ & $\begin{array}{l}\text { 1. Melakukan kegiatan penilaian sesuai dengan rencana } \\
\text { penilaian yang telah disusun diawal kegiatan } \\
\text { pembelajaran, } \\
\text { 2. Menganalisis kualitas instrumen dengan mengacu pada } \\
\text { persyaratan instrumen } \\
\text { 3. Pelaksanaan ulangan dan ujian yang bebas dari } \\
\text { kemungkinan terjadi tindak kecurangan, } \\
\text { 4. Memeriksa pekerjaan peserta didik dan memberikan } \\
\text { umpan balik dan komentar yang bersifat mendidik. }\end{array}$ \\
\hline $\begin{array}{l}\text { 3. Hasil/Dampak } \\
\text { (outcomes) }\end{array}$ & $\begin{array}{l}\text { 1. Hasil belajar dapat mencapai target yang ditetapkan pada } \\
\text { KKM matapelajaran } \\
\text { 2. Pemberian dan penggabungan skor yang diperoleh dari } \\
\text { berbagai teknik dengan bobot tertentu sesuai dengan } \\
\text { aturan yang telah ditetapkan. } \\
\text { 3. Bagi siswa yang belum mencapai standar ketuntasan, } \\
\text { pendidik harus melakukan pembelajaran remidial, agar } \\
\text { setiap siswa dapat mencapai standar ketuntasan yang } \\
\text { dipersyaratkan; } \\
\text { 4. Penyampaian dan pelaporan hasil penilaian kepada orang } \\
\text { tua/ wali murid }\end{array}$ \\
\hline
\end{tabular}




\section{HASIL PENELITIAN DAN PEMBAHASAN}

\section{Deskripsi aspek Perencanaan (Antecedents)}

Deskripsi aspek perencanaan evaluasi implementasi standar penilaian oleh guru matematika di SMA Negeri 3 Watampone dapat dilihat pada Tabel 3.

Tabel 3 Deskripsi Aspek perencanaan evaluasi implementasi standar penilalain oleh guru matematika di SMA Negeri 3 Watampone

\begin{tabular}{cccc}
\hline Interval & Frekuensi & Persen $(\%)$ & Kategori \\
\hline skor $\geq 101$ & 5 & 100 & Sangat baik \\
$79 \leq$ skor $<101$ & 0 & - & Baik \\
$56 \leq$ skor $<79$ & 0 & - & Cukup \\
$34 \leq$ skor $<56$ & 0 & - & Kurang \\
skor $<34$ & 0 & - & Sangat kurang \\
\hline Jumlah & 5 & 100 & 100 \\
\hline & & & Sumber : Penelitian 2014
\end{tabular}

Dari Tabel 2 dapat dideskripsikan bahwa evaluasi implementasi standar penilaian oleh guru matematika di SMA Negeri 3 Wtampone dari aspek perencanaan berada pada kategori sangat baik.

Berdasarkan hasil analisis dokumen bahwa guru merencanakan penilaian dengan menyiapkan perangkat pembelajaran yang sesuai seperti silabus, RPP, media pembelajaran, buku ajar dan LKS. Perangkat tersebut menjadi pedoman dan rujukan dalam satu tahun pembelajaran serta mempermudah guru untuk mencapai standar kompetensi sebagaimana tuntutan kurikulum. Salah satu perangkat pembelajaran yang disusun guru yakni merencanakan penilaian secara terpadu dengan silabus dan RPP.

Dari hasil wawancara dengan 5 informan guru matematika menginformasikan bahwa dalam melakukan penilaian telah memiliki instrument hasil belajar yang memenuhi persyaratan substansi, konstruksi, dan bahasa. Guru juga melaksanakan penilaian non tes, akan tetapi belum maksimal, khususnya teknik observasi, guru hanya melakukannya pada saat proses pembelajaran berlangsung, tidak dilakukan diluar kegiatan pembelajaran.

\section{Deskripsi Aspek Pelaksanaan (Transactions)}

Deskripsi aspek proses/pelaksanaan evaluasi implementasi standar penilaian oleh guru matematika di SMA Negeri 3 Watampone dapat dilihat pada Tabel 1.4. 
Tabel 4 Deskripsi aspek Pelaksanaan (Transactions) evaluasi implementasi standar penilaian oleh guru matematika di SMA Negeri 3 Watampone

\begin{tabular}{cccc}
\hline Interval & Frekuensi & Persen (\%) & Kategori \\
\hline skor $\geq 142$ & 5 & 100 & Sangat baik \\
$110 \leq$ skor $<142$ & - & - & Baik \\
$79 \leq$ skor $<110$ & - & - & Cukup \\
$47 \leq$ skor $<79$ & - & - & Kurang \\
skor $<47$ & - & - & Sangat kurang \\
\hline Jumlah & 5 & 100 & 100 \\
\hline
\end{tabular}

Pada Tabel 4. dideskripsikan bahwa hasil rekapitulsi pelaksanaan (transactions) pada evaluasi implementasi standar penilaian oleh guru matematika di SMA Negeri 3 Watampone berada pada kategori sangat baik.

Pelaksanaan penilaian adalah penyajian penilaian kepada peserta didik. Penilaian dilaksanakan dalam suasana kondusif, tenang dan nyaman dengan menerapkan prinsip valid, objektif, adil, terpadu, terbuka, menyeluruh, menggunakan acuan kriteria, dan akuntabel. Penilaian pendidikan adalah proses pengumpulan dan pengolahan informasi untuk menentukan pencapaian hasil belajar peserta didik.

Pelaksanaan penilaian sesuai dengan standar yang mengacu pada standar penilaian di SMA Negeri 3 Watampone sudah dilaksanakan guru meskipun belum maksimal seperti yang kita harapkan. Hasil wawncara dengan peserta didik menginformasikan bahwa pada proses pelaksanaan penilaian khususnya di dalam kelas sudah berjalan baik dengan guru matematika dalam melaksanakan penilaian merujuk pada silabus dan RPP yang telah dibuat sebelum proses pembelajaran berlangsung. Ditinjau dari aspek tugas yang diberikan setiap pertemuan, guru memberikan tugas apabila selesai mengajarkan satu kompetensi dasar. Tugas setiap pertemuan bertujuan untuk mengetahui pemahaman peserta didik terkait materi yang telah diajarkan. Soal tugas dapat diambil dari buku paket yang digunakan maupun soal di RPP dibuat sendiri oleh guru. Bentuk tugas berupa pilihan ganda, uraian, dan lembar kerja. (wawancara peserta didik, 1 Mei 2014).

Senada dengan hasil wawncara peserta didik diatas, hasil analisis dokumen juga mengungkapkan bahwa pelaksanaan penilaian yang telah dirancang di RPP sejalan dengan silabus yang ada (Analisis dokumen). Ditinjau dari aspek tugas yang diberikan setiap pertemuan, kecenderungan guru matematika memberikan tugas apabila selesai mengajarkan satu kompetensi dasar. Soal tugas yang diberikan kepada peserta didik diambil dari buku paket 
peserta didik dan buku paket yang digunakan oleh guru. Bentuk tugas berupa kuis, portofolio, pengisian dan lembar kerja yang ada dibuku paket. Hasil analisis dokumen, bentuk tes yang digunakan oleh guru dalam bentuk uraian. Hal ini dikarenakan tes uraian lebih mudah dalam pembuatannya. Jumlah soal minimal 2 nomor uraian. Selain tes uraian, guru memberikan soal tugas dibuku paket berupa lembar kerja, tugas proyek dan pengisian di buku kerja peserta didik. Hal ini sejalan dengan hasil wawancara (3 Mei 2014) dengan salah satu peserta didik bahwa memang guru matematika pada setiap awal pembelajaran menyampaikan tujuan pembelajarannya, dan guru memberikan tugas pada setiap akhir pembelajaran dalam bentuk essay dan pilihan ganda.

Tugas guru setelah melaksanakan penilaian yakni memeriksa pekerjaan peserta didik dan memberikan umpan balik dan komentar yang bersifat mendidik. Hasil wawancara dengan peserta didik, mengatakan guru memberi komentar terhadap hasil pekerjaan peserta didik secara lisan pada saat pengembalian lembar jawaban kepada peserta didik. Guru memberikan kesempatan kepada peserta didik untuk mengoreksi jawaban yang berbeda dengan guru, maka guru langsung bertanya alasan kenapa memilih jawaban itu. Sehingga antara peserta didik dan guru saling tukar informasi mengenai materi yang belum dipahami oleh peserta didik.

Selanjutnya, hasil penilaian peserta didik dapat menjadi tolak ukur tercapainya tujuan pembelajaran. Jika terdapat peserta didik yang belum mencapai tujuan pembelajaran maka, guru melakukan remedial. Namun remedial yang dilaksanakan berdasarkan hasil wawancara dengan responden peserta didik mengatakan bahwa, pelaksanaan remedial dilakukan guru mtematika di sekolah dengan memberikan soal yang belum tuntas. (wawancaara 3 Mei 2014).

Penilaian yang dilakukan di sekolah mengacu pada standar penilaian PAK (Penilaian Acuan Kriteria). PAK adalah penilaian yang menggunakan acuan pada tujuan pembelajaran atau kompetensi yang harus dikuasai peserta didik. Hasil yang dicapai peserta didik dibandingkan dengan kriteria atau standar yang ditetapkan. Penilaian merupakan bagian dari proses pendidikan yang dapat memacu dan memotivasi peserta didik untuk lebih berprestasi meraih tingkat yang setinggi-tingginya sesuai dengan kemampuannya. Hasil wawancara dengan peserta didik, (wawancara 3 Mei 2014) bahwa guru matematika memberi motivasi kepada kami jika kami mendapatkan nilai dibawah KKM (Kriteria Ketuntasan Minimal). Guru juga menilai dengan adil, tidak membeda-bedakan antara peserta didik yang satu dengan yang lainnya. Jika peserta didik mendapatkan nilai di bawah KKM maka peserta didik itu harus mengikuti remedial. Remedial dilakukan oleh guru satu minggu setelah pelaksanaan ulangan dengan memberikan soal yang belum tuntas. 
Untuk memperkuat data hasil penelitian evaluasi ini, maka diedarkan angket kepada 90 responden peserta didik yang dimaksudkan untuk memperoleh data yang lebih akurat tentang pelaksanaan penilaian oleh guru SMA Negeri 3 Watampone, yang hasilnya terlihat pada Tabel 5.

Tabel 5. Deskripsi hasil kuesioner peserta didik aspek pelaksanaan (Transactions) evaluasi implementasi standar penilaian oleh guru matematika di SMA Negeri 3 Watampone

\begin{tabular}{cccc}
\hline Interval & Frekuensi & Persen (\%) & Kategori \\
\hline skor $\geq 64$ & 85 & 94,44 & Sangat baik \\
$49 \leq$ skor $<64$ & 5 & 5,56 & Baik \\
$35 \leq$ skor $<49$ & 0 & & Cukup \\
$21 \leq$ skor $<35$ & 0 & & Kurang \\
skor $<21$ & 0 & 100 & Sangat kurang \\
\hline Jumlah & 90 & & \\
\hline
\end{tabular}

Sumber : Penelitian 2014

Pada Tabel 5 dideskripsikan bahwa hasil kuesioner peserta didik pada pelaksanaan (transactions) evaluasi implementasi standar penilaian oleh guru matematika di SMA Negeri 3 Watampone, kategori baik 5,56 persen, dan kategori sangat baik 94,44 persen, sehingga berdasarkan hasil kuesiner diatas bahwa evaluasi pelaksanaan (transactios) implementasi standar penilaian oleh guru matematka di SMA Negeri 3 Watampone sebagian besar berada pada kategori sangat baik.

\section{Deskripsi Aspek Pelaporan Hasil/Dampak (Outcomes)}

Penilaian hasil belajar matematika merupakan kegiatan yang dilakukan guru matematika untuk memperoleh informasi tentang pencapaian tujuan, proses dan hasil belajar dalam waktu tertentu. Evaluasi proses dan hasil belajar merupakan serangkaian kegiatan yang dilaksanakan tahap demi tahap berdasarkan keseluruhan hasil penilaian yang dilakukan. Berdasarkan hasil penilaian, pendidik dapat mengambil keputusan secara tepat untuk menentukan langkah yang harus dilakukan selanjutnya. Hasil penilaian bermanfaat bagi peserta didik untuk bimbingan, membantu dan mengarahkan yang berkaitan dengan studinya. Oleh karena itu, penilaian tidak hanya untuk mencapai target sesaat, melainkan menyeluruh dan mencakup kompetensi pengetahuan, sikap serta keterampilan. 
Deskripsi tentang pelaporan hasil belajar peserta didik diukur dengan menggunakan 8 item pernyataan. Hasil nilai kuesiner yang diperoleh dari 5 orang responden disajikan Tabel 6.

Tabel 1.6. Deskripsi aspek pelaporan hasil belajar peserta didik pada evaluasi implementasi standar penilaian oleh guru matematika d SMA Negeri 3 Watampone

\begin{tabular}{cccc}
\hline Interval & Frekuensi & Persen (\%) & Kategori \\
\hline skor $\geq 30$ & 3 & 60 & Sangat baik \\
$23 \leq$ skor $<30$ & 2 & 40 & Baik \\
$17 \leq$ skor $<23$ & 0 & - & Cukup \\
$10 \leq$ skor $<17$ & 0 & - & Kurang \\
skor $<10$ & 0 & - & Sangat kurang \\
\hline Jumlah & 5 & 100 & \\
\hline
\end{tabular}

Pada Tabel 6 dideskripsikan bahwa hasil penelitian pelaporan hasil belajar peserta didik pada evaluasi implementasi standar penilaian oleh guru matematika di SMA Negeri 3 Watampone, kategori baik 40 persen, dan kategori sangat baik 60 persen, sehingga pelaporan hasil belajar peserta didik pada implementasi standar penilaian oleh guru matematka di SMA Negeri 3 Watampone sebagian besar berada pada kategori sangat baik.

Deskripsi outcomes (hasil) tentang pelaksanaan standar penilaian dapat dijelaskan berikut ini.

Pertama, hasil dokumen menginformasikan bahwa setelah pemeriksaan hasil tugas, ulangan, maupun ujian peserta didik guru langsung memasukkan dalam buku daftar nilai yang telah disediakan oleh sekolah. Selanjutnya, pendidik melakukan kegiatan menghitung/menetapkan nilai mata pelajaran dari berbagai macam penilaian (hasil ulangan harian, tugas-tugas, ulangan tengah semester, dan ulangan akhir semester atau ulangan kenaikan kelas). Apabila terdapat peserta didik yang belum mencapai KKM, guru melaksanakan remedial untuk mencapai target yang telah ditentukan. Setelah itu, guru melengkapi daftar nilai yang belum terisi, lalu melaporkan pada wali kelas. Teknik penskoran mengacu pada pedoman konversi nilai yang ditentukan oleh sekolah. Pelaporan hasil penilaian disajikan dalam bentuk profil hasil belajar peserta didik.

Kedua, hasil penilaian dapat dijadikan informasi bagi orang tua/wali murid. Sesuai dengan prinsip penilaian mengenai transparansi. Transparansi berarti prosedur penilaian, kriteria penilaian, dan dasar pengambilan keputusan dapat diakses oleh semua pihak lain. Jika

Evaluasi Implementasi Standar Penilaian oleh Guru Matematika 
guru matematika menemukan peserta didik yang mengalami kesulitan belajar, maka guru mengundang orang tua/wali murid untuk menemukan solusi penyelesaian masalah.

Pertemuan antara guru dan wali murid akan menjelaskan perkembangan peserta didik, kendala yang dihadapi peserta didik di dalam kelas, serta pemberian motivasi untuk peningkatan prestasi akademik yang lebih baik ke depannya. Guru matematika menyetor nilai ke wali kelas, lalu kemudian wali kelas menulisnya dalam rapor. Rapor merupakan bentuk pelaporan hasil belajar peserta didik kepada orang tua/wali murid, sehingga rapor dapat menginformasikan prestasi dan perkembangan peserta didik dalam mengikuti proses pembelajaran yang dilakukan selama 1 atau 2 semester.

Informasi yang didapat mulai dari deskripsi perencanaan (antecedents), antecedent), proses (transactions), hasil (outcomes), kemudian peneliti membandingkan kondisi riil yang ditemukan di lapangan dengan kriteria ideal standar pelaksanaan penilaian menurut peraturan Menteri Pendidikan dan Kebudayaan Republik Indonesia nomor 66 Tahun 2013 disajikan pada Tabel 7.

Tabel 7. Perbandingan kondisi riil yang ditemukan di lapangan dengan kriteria ideal standar penilaian guru Matematika.

\begin{tabular}{|c|c|c|c|c|}
\hline No & Kondisi Riil & 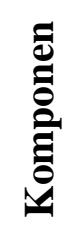 & Kondisi ideal & Ket. \\
\hline 1 & $\begin{array}{l}\text { Guru telah menyusun RPP } \\
\text { yang dibutuhkan sebelum } \\
\text { kegiatan pembelajaran } \\
\text { dimulai sesuai dengan } \\
\text { silabus. }\end{array}$ & \multirow{4}{*}{ 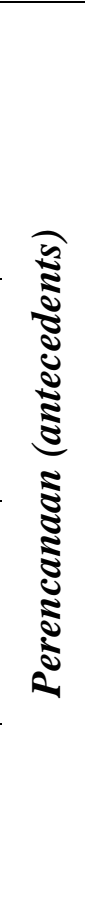 } & $\begin{array}{l}\text { Kesesuaian antara perencanaan } \\
\text { penilaian secara terpadu dengan } \\
\text { silabus dan rencana } \\
\text { pembelajarannya }\end{array}$ & Sesuai \\
\hline 2 & $\begin{array}{l}\text { Guru mengembangkan } \\
\text { kriteria pencapaian } \\
\text { kompetensi }\end{array}$ & & $\begin{array}{l}\text { Mengembangkan kriteria } \\
\text { pencapaian kompetensi dasar } \\
\text { (KD) sebagai dasar untuk } \\
\text { penilaian }\end{array}$ & Sesuai \\
\hline 3 & $\begin{array}{l}\text { Membuat instrumen } \\
\text { berdasarkan kisi-kisi. }\end{array}$ & & $\begin{array}{l}\text { Membuat instrumen } \\
\text { berdasarkan kisi-kisi yang telah } \\
\text { dibuat dan dilengkapi dengan } \\
\text { pedoman penskoran }\end{array}$ & Sesuai \\
\hline 4 & $\begin{array}{l}\text { Tidak ada rubrik penilaian } \\
\text { dalam menilai kompetensi } \\
\text { sikap. }\end{array}$ & & $\begin{array}{l}\text { Teknik penilaian dan instrumen } \\
\text { penilaiannya sesuai indikator } \\
\text { pencapaian KD }\end{array}$ & $\begin{array}{l}\text { Tidak } \\
\text { sesuai }\end{array}$ \\
\hline
\end{tabular}

Evaluasi Implementasi Standar Penilaian oleh Guru Matematika 


\begin{tabular}{|c|c|c|c|c|}
\hline 5 & $\begin{array}{l}\text { Menggunakan acuan } \\
\text { kriteria dengan mengacu } \\
\text { pada KKM }\end{array}$ & & $\begin{array}{l}\text { Menggunakan acuan kriteria } \\
\text { dalam menentukan nilai peserta } \\
\text { didik }\end{array}$ & Sesuai \\
\hline 1 & $\begin{array}{l}\text { Pelaksanaan penilaian } \\
\text { tugas, ulangan harian, dan } \\
\text { ujian yang dilakukan sesuai } \\
\text { dengan perencanaan }\end{array}$ & \multirow{4}{*}{ 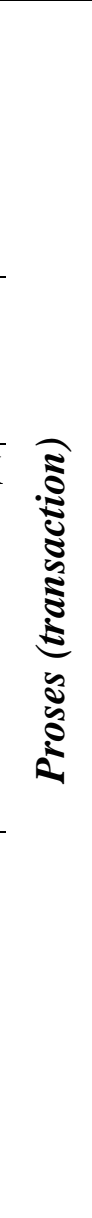 } & $\begin{array}{l}\text { Melakukan kegiatan penilaian } \\
\text { sesuai dengan rencana penilaian } \\
\text { yang telah disusun diawal } \\
\text { kegiatan pembelajaran }\end{array}$ & Sesuai \\
\hline 2 & $\begin{array}{l}\text { Validasi instrumen } \\
\text { dilakukan dengan teman } \\
\text { sejawat }\end{array}$ & & Menganalisis kualitas instrumen & Sesuai \\
\hline 3 & $\begin{array}{l}\text { Pelaksanaan UAS dan UKK } \\
\text { dilakukan dengan } \\
\text { koordinasi sekolah dan ada } \\
\text { tim screening soal. Ujian } \\
\text { diawasi secara ketat, } \\
\text { terdapat dua pengawas } \\
\text { dalam satu ruangan. } \\
\end{array}$ & & $\begin{array}{l}\text { Pelaksanaan ulangan dan ujian } \\
\text { yang bebas dari kemungkinan } \\
\text { terjadi tindak kecurangan }\end{array}$ & Sesuai \\
\hline 4 & $\begin{array}{l}\text { Guru memberikan umpan } \\
\text { balik, berupa komentar } \\
\text { yang sifatnya memotivasi. } \\
\text { Pelaksanaan remedial } \\
\text { dengan memberi ulang soal } \\
\text { yang telah diujikan. }\end{array}$ & & $\begin{array}{l}\text { Memeriksa pekerjaan peserta } \\
\text { didik dan memberikan umpan } \\
\text { balik dan komentar yang } \\
\text { bersifat mendidik, kemudian } \\
\text { memberikan remedial bagi } \\
\text { peserta didik yang belum } \\
\text { mencapai KKM. }\end{array}$ & $\begin{array}{l}\text { Tidak } \\
\text { sesuai }\end{array}$ \\
\hline 1 & $\begin{array}{l}\text { Tidak semua hasil belajar } \\
\text { matematika peserta didik } \\
\text { berhasil mencapai KKM }\end{array}$ & \multirow{3}{*}{ 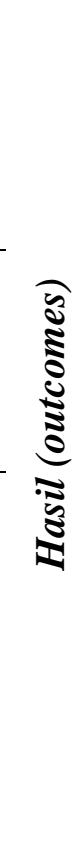 } & $\begin{array}{l}\text { Hasil belajar matematika dapat } \\
\text { mencapai target yang } \\
\text { ditetapkan pada KKM } \\
\text { matapelajaran }\end{array}$ & $\begin{array}{l}\text { Tidak } \\
\text { sesuai }\end{array}$ \\
\hline 2 & $\begin{array}{l}\text { Pemberian skor 1-100 dan } \\
\text { mengabungkan nilai, tugas, } \\
\text { UH, UAS, dan UKK sebgai } \\
\text { nilai Rapor }\end{array}$ & & $\begin{array}{l}\text { Pemberian skor dan } \\
\text { penggabungan skor }\end{array}$ & Sesuai \\
\hline 3 & $\begin{array}{l}\text { Hasil penilaian dilaporkan } \\
\text { kepada wakil kepala } \\
\text { sekolah dan wali kelas. } \\
\text { setelah itu, mengundang } \\
\text { wali murid/orang tua } \\
\text { peserta didik untuk } \\
\text { mengambil rapor. }\end{array}$ & & $\begin{array}{l}\text { Penyampaian dan pelaporan } \\
\text { hasil penilaian kepada orang } \\
\text { tua/ wali murid }\end{array}$ & Sesuai \\
\hline
\end{tabular}


Hasil penilaian dapat dijadikan informasi bagi wali murid. Sesuai dengan prinsip penilaian yakni transparan. Tranparans berarti prosedur penilaian, kriteria penilaian, dan dasar pengambilan keputusan dapat diakses oleh semua pihak lain. Guru melakukan komunikasi dengan orang tua/wali murid berlangsung di saat proses pembelajaran maupaun hasil belajar peserta didik. Hal ini sejalan dengan pendapat Rasyid dan Mansyur (2009: 55), bahwa hasil penilaian dapat dijadikan informasi bagi orang tua untuk: (1) membantu anaknya belajar, (2) memotivasi anaknya belajar, (3) membantu sekolah untuk meningkatkan hasil belajar peserta didik, dan (4) membantu sekolah dalam melengkapi fasilitas belajar. Jika guru matematika menemukan peserta didik yang mengalami kesulitan belajar, maka guru matematika mengundang orang tua/wali untuk menemukan solusi penyelesaian masalah. Pertemuan antara guru dan wali kelas akan menjelaskan perkembangan peserta didik, kendala yang dihadapi peserta didik di dalam kelas, serta pemberian motivasi untuk peningkatan prestasi akademik yang lebih baik ke depannya. (Anne Ruggles Gere, 2010)

\section{KESIMPULAN}

Berdasarkan hasil penelitian yang telah dianalisis, maka dapat disimpulkan bahwa evaluasi implementasi standar penilaian oleh guru matematika di SMA Negeri 3 Watampone dapat diuraikan sebagai berikut:

1. Implemntasi standar penilaian oleh guru matematika di SMA Negeri 3 Watampone pada tahap perencanaan (antecedents) belum terlaksana satu dari lima kriteria standar penilaian pendidikan.

2. Implemntasi standar penilaian oleh guru matematika di SMA Negeri 3 Watampone pada tahap proses (transactions) dari empat kriteria standar penilaan pendidikan telah terlaksana secara menyeluruh.

3. Implemntasi standar penilaian oleh guru matematika di SMA Negeri 3 Watampone pada tahap hasil (outcomes) belum terlaksana satu dari empat kriteria standar penilaian pendidikan. 


\section{DAFTAR PUSTAKA}

Anne, R.G., Moody, S., Pugh, M., Toth C., \& VanKooten, C. (2010). Fostering High-Quality Formative Assessment 2010. University of Michigan.

Arikunto, S. \& Jabar, C.S. (2010). Evaluasi Program Pendidikan. Jakarta: Bumi Aksara.

Arikunto, S. (2009). Dasar-Dasar Evaluasi Pendidikan. Jakarta: Bumi Aksara.

Chandra, K. (2013). Studi Implementasi Standar Penilaian Pendidikan Oleh Guru Fisika Sma Di Kota Medan. UNIMED Press.

Damin, S. 2010. Profesionalisasi dan Etika Profesi Guru. Bandung: CV Alfabeta

Depdiknas RI. 2003. Undang-Undang Republik Indonesia Nomor 20 Tahun 2003 Tentang Sistem Pendidikan Nasional. Jakarta : Depdiknas.

Farouk, M. \& Djali. (2003). Metodologi Penelitian Sosial. Jakarta: PTIK Press Jakarta - CV. Restu Agung.

Haryati, M. (2006). Sistem Penilaian Berbasis Kompetensi. Jakarta: Gaung persada Press.

Katrien Struyven And Filip Dochy And Steven Janssens. 2005. Students' perceptions about evaluation and assessment in higher education: a reviewAssessment \& Evaluation in Higher Education Vol. 30, No. 4, August 2005, pp. 331-347 University of Leuven (KULeuven), Belgium. (diakses pada 31 Juli 2014)

Maddalena, T. (2005). Assessment - Summative And Formative -some theoretical reflections. British Journal of Educational Studies, 53(4), 466-478.

Mansyur, R.S. (2009). Assesmen Pembelajaran di Sekolah. Yogyakarta : Multi Pressindo.

Mansyur \& Hamda. (2012). Pengembangan Model Penilaian Diri untuk Membangun Karakter dan Prestasi Siswa pada Pembelajaran Matematika di SMP. Laporan Penelitian Hibah Penelitian Hibah Bersaing Tahun 2011. Makassar: Lembaga UNM

Mardapi, D. (2012). Pengukuran Penilaian \& Evaluasi Pendidikan. Yogyakarta: Nuha Litera.

Moleong, L.J. (2005). Metodologi penelitian kualitatif. Bandung: PT Remaja Rosdakarya.

Munarfah, A. \& Muhammad, H. (2009). MetodePenelitian. Jakarta: Praktika Aksara Semesta.

Nur, S.M. (2013). Pengembangan Perangkat Penilaian Kinerja Peserta Didik Pada Materi Pokok Sistem Ekskresi. Tesis Tidak Diterbitkan. Makassar: UNM.

Peraturan Menteri Pendidikan dan Kebudayaan Republik Indonesia Nomor 66 Tahun 2013 Tentang Standar Penilaian Pendidikan.

Peraturan Menteri Pendidikan Pendidikan Dan Kebudayaan Republik Indonesia Nomor 70 Tahun 2013 Tentang Kerangka Dasar Dan Struktur Kurikulum Sekolah Menengah Kejuruan/Madrasah Aliyah Kejuruan.

Peraturan pemerintah Pasal 60 No. 19 Tahun 2005. Tentang Sistem Penilaian Pendidikan pada Jenjang Dasar dan Menengah.

Evaluasi Implementasi Standar Penilaian oleh Guru Matematika 
Puspita, E. (2010). Triangulasi (online) (http://3lox.wordpress.com, diakses 14 April 2014

Salehuddin, Y. (2010). Pengelolaan Pembelajaran. Makassar: UIN Press.

Sutomo. (1985). Teknik Penilaian Pendidikan. Surabaya: Bina Ilmu

Sudjana, N. (2012). Penilaian Hasil Proses Belajar Mengajar. Bandung PT Remaja Rosdakarya.

Tayibnapis, F.Y. (2008). Evaluasi Program dan Instrumen Evaluasi. Jakarta: Rineka Cipta.

Uno, H.B. \& Satria, K. (2012). Assessment Pembelajaran. Jakarta: Bumi Aksara.

Wayan, N. \& Sumartana. (1983). Evaluasi pendidikan Surabaya-Indonesia : Usaha Nasional.

Wirawan. (2011). Evaluasi; Teori, Model, Standar, Aplikasi dan Profesi. Jakarta: Rajagrafindo Persada. 